parallel, variations in numbers employed being positively associated with similar variations not only in the mere numbers of accidents but also with the risk of incurring them. Of the more personal aspects of industry, Sir Duncan does not think that the loss of paternalism involved in modern times in the formation of large combines replacing or absorbing the small employers is a pure loss, but emphasizes that many and probably most of the small employers were first concerned with profit and lastly with the safety, health and general interests of their workers. $\mathrm{He}$ refers to the noticeable change in the workers themselves and asserts that the bedraggled, illmannered and ill-spoken worker has been replaced by one with self-respect, good appearance and the best manners of any social class. Sir John Forbes Watson, in the discussion which followed, referred to the importance of the analysis of factory conditions in Great Britain as compared with others and the importance of developments in industrial medicine was stressed by Dr. H. B. Morgan, who paid a particularly warm tribute to the work of the factory medical inspectors. Mr. Robert R. Hyde, director of the Industrial Welfare Society, in a written communication, referred to the importance of ways and means of providing the smaller units of industry with some form of the medical service which has already been developed with such success in many large firms.

\section{RECONSTRUCTION AND ECONOMICS}

TN a pamphlet entitled "Post-War Poverty and Unemployment Can be Prevented" issued last year (see NATuRE, 146, 312; 1940) T. W. Wyatt and D. Caradog Jones challenged the assumption that a period of intense economic depression and serious unemployment is bound to follow the War, and urged that, on the contrary, it should be possible by a carefully thought-out plan, co-ordinating all forms of industrial activity, to change over from war production to peace production, utilizing the vastly improved capacity of production for creating new wealth. A postscript by J. R. Bellerby outlined five stages by which this could be achieved. Messrs. Wyatt and Caradog Jones have now, under the title "Britain's New Order"*, issued as a sequel a further thoughtful study of methods of preventing post-war unemployment, which deals with some of the questions and doubts raised by their earlier pamphlet.

The pamphlet urges that local authorities should be encouraged to prepare schemes of work to put into operation as soon as ever private demand slows down after the burst of activity which may be anticipated immediately after the War. Government departments which are able to do so should set an example by initiating public works when the suitable moment arrives. The appointment of a commission with members drawn from all walks of life and responsible to Parliament is suggested to decide which schemes of public work should have preference and to regulate the purchase of surplus foods and materials for storage in different parts of the country. The criterion for determining the approval of or vetoing of any particular scheme should be its consistency with, or opposition to, the public interest.

*Britain's "New Order" : a Plea for a Sane Post-War Employment Policy. By T. W. Wyatt. and D. Caradog Jones. Pp. 32. (Birkenhead: John WooIman and Sons, 1941.) 9d.
Every effort should be made to decentralize as much as possible and to interfere as little as possible with private initiative, subject only to the over-riding conditions that the national and municipal interest must come first.

Messrs. Wyatt and Jones urge that modern powers of production are so vast that they must be regulated or they will overwhelm us. It is within our power at the end of the War to build a new world, but we must scrap our old impressions of scarcity and of the need for all-round sacrifice to pay for the War. Taxes, accordingly, they consider should be made as light as possible, and they should be raised or lowered solely for the purpose of regulating purchasing power.

Money or credit required to keep production and exchange functioning should be created directly by the Government up to a strict limit when labour, machinery and materials were all fully and efficiently employed. This demands a high degree of skilled organization for which training and time may be required, and although Messrs. Wyatt and Jones believe that no radical change in the present economic system is required, they point out that sudden transition from a system based on production for profit to a new system based on production for use would be dangerous. The present system can be made to provide a much higher standard of life than we have hitherto enjoyed, and this higher standard will permit us to acquire the better education which is the pre-requisite for the organization of a more rational and efficient system of production for use and service.

All the machinery for a great forward stride, given the right direction and control, is at our command. The large surpluses of all kinds of commodities which are piling up in various parts of the world are as important to the countries of their origin as to those that receive them. Much of the urgent reconstruction required over a wide area will be completed in a relatively short time, and all this work must be undertaken regardless of cost. Purchasing power is the key to distribution, and the solution of the problem of distribution will remove one of the most potent obstacles in the path of a settled peace.

In their attempt to build on past experience, the authors are undoubtedly in keeping with the British tradition, and the work which it is proposed should be entrusted to a Parliamentary Commission is already largely in the hands of the Cabinet Committee under Mr. Arthur Greenwood, the Ministry of Works and Building, or the Leith-Ross Bureau.

Essentially the same ideas are outlined in two artıcles which have appeared in the October number of the American periodical Fortune. In the first of these, Mr. Geoffrey Crowther, editor of the Economist, at present visiting the United States, enters a powerful plea for a political democracy which includes a balance, and not merely a mixture, of the social and the profit motives. Mr. Crowther suggests, for example, that the whole of the question of food supply should be removed, in peace as in war, from the operation of the profit motive, and the incentive of order, or purposeful organization by the community, substituted for that of freedom and private profit, in much the same way that education is already organized on a service basis. The concept of social security, however, should not be limited to the satisfaction of basic needs. The extended Bill of Rights must be accompanied by an extended Bill of Duties including specific social service, whether in the defence forces, the health services, or in what- 
ever special sphere the particular citizen may be best qualified to serve.

Such service would very materially ease the financial burden of the Citizen's Charter, and Mr. Crowther then suggests that over the remaining half of the national economy where the incentive of profit would continue to function, subject to the watching brief of the Govermment as trustee for the community, it is important to take the brakes off enterprise, and stimulate economic activity with the view of stimulating employment. The profit motive, he urges, is in dire need of assistance, and like Wyatt and Jones, he attacks the policy of excessive taxation as well as repression of enterprise or individuality through monopolies, cartels, trade associations, or the like. When the basic needs of the citizen have been met and his strongest fears removed, it is in an atmosphere of freedom that the human spirit can develop its full powers, and he contends that it should be possible for both the Left and the Right to accept a balance between freedom and order.

Mr. A. A. Berle, jun., Assistant Secretary of State, in an article on post-war development, urges that every defence industry should have a research staff working on plans for producing peace-time goods. A conference should be held to take inventory of these plans and to lay out a catalogue of the products that will be available when the War ends. This catalogue should be matched against known needs of the country for reconstruction, including such needs as relocation and modernization of city areas, new housing for several millions of families, public works, and nutrition, adequate in kind and quality to ensure public health. These needs are potential markets. Out of these and others like them there should be constructed markets sufficient to ensure full use of our plants and full employment for all our people.

Finance, Mr. Berle argues, is a technical problem, like engineering. We can afford anything for which we have materials, labour and reasonable needs. These are the only stop signs, and common-sense adjustment of war finance to peace finance will permit construction of markets to the extent necessary. Like Messrs. Wyatt and Jones, Mr. Berle is convinced as to the richness of the new era that nrodern technique puts within our reach, and he concludes with the reminder that economics tends to reflect the desires and wants of a country, and whether our new order is to be an enduring and stable order will depend above all on its moral basis.

\section{FORTHCOMING EVENTS}

\section{Saturday, January 24}

BRITISH RHEOLOGISTS' Club (in the Department of Physics, The University, Birmingham), at 1.15 p.m.-Discussion on "Classifications of Rheological Properties":

\section{Monday, January 26}

Royal Society of ARTS (at John Adam Street, Adelphi, London, W.C.2), at 1.45 p.m.-Dr. B. A. Keen, F.R.S. : "Soil Physics, Theory and Practice" (Cantor Lectures, II).

RoYal Ghographical SogiETY (at Kensington Gore, London, S.W.7), at 3 p.m.-Kodachrome Films by Mrs. Patrick Ness : "Burma, Indo-China, Thailand and Netherlands Indies".

INSTITUTION of Electrical ENGINeERs (at Savoy Place, London W.C.2), at 5 p.m. - Discussion on "Is there an Electrical Basis for Water Divining?" (To be opened by Mr. J. F. Shipley).

\section{Wednesday, January 28}

Rorar Sodrwy of ARTS (at John Adam Street, Adelphi, London, W.C,2), at 1.45 p.m.-Mr. F. R. Yerbury : "The Post-War Home Its
INSTITUTR OF PHYSICS (IONDON AND HOME COUNTIES' BRANCH) (at the Royal Institution, Albemarle Street, London, W.1), at 2 p.m $\rightarrow$ Conference on "Electronics" (Chairman: Prof. J. D. Cockeroft, F.R.S.).

ROYAL METEOROLogtodu Socrety (at 49 Cromwell Road, London, S.W.7), at 4.30 p.m.-Annual General Meeting. Sir George Simpson, Address).

\section{APPOINTMENTS VACANT}

Applications are Invited for the following appointments on or before the dates mentioned:

Civil Enginefring assistant experienced in LaND Drainagr Works-The Clerk to the River Trent Catchment Board, Catchment Board Offices, Derby Road, Nottingham (January 30).

Borodgh Electrical ENGINERR-The Town Clerk, Town Hall, Burnley (endorsed 'Borough Electrical Engineer') (January 31).

Igoturer iN Electrical Enginearing-The Principal, County Technical College, Guildford, Surrey (January 31).

LeOTURTR IN MEOHANICAL ENGINERRING-The Principal, Handsworth Technical College, Golds Hill Road, Handsworth, Birmingham 21.

IEOTURER IN ELFCTRICAL ENGINEARING-The Registrar, Wimbledon Technical College, Gladstone Road, London, S.W.19.

Lecturer in Mfehanical Engineering SubJects-The Principal, Kingston-upon-Thames Technical College, Kingston-upon-Thames, Surrey

\section{REPORTS and other PUBLICATIONS}

\author{
(not included in the monthly Books Supplement)
}

\section{Great Britain and Ireland}

University of Leeds. Report of the Librarian for the Session 1940-41. P. 5. (Leeds: The University.) [2412

Proceedings of the Royal Society of Edinburgh. Section A (Mathematical and Physical Sciences). Vol. 61, Part 2 , No. 11 : Quantum Theory of the Chemical Bond. By C. A. Coulson. Pp. 115-139. 28. Vol. 61, Part 2, No. 12: Some Remarks occasloned by the Geometry of the Veronese Surface. By W. L. Edge. Pp. 140-159. 18. 9d. (Edin-
burgh and London: Oliver and Boyd.)
[2412

$[2412$

National Central Library. 25th Annual Report of the Executive Committee, 1940-1941. Pp. 16. (London: National Central Library.) [11

\section{Other Countries}

Transactions of the San Diego Society of Natural History. Vol. 9, No. 29: The Long-Nosed Snakes of the Genus Rhinocheilus. By Laurence M. Klauber. Pp. 289-332 + plates 12-13. Vol. 9, No. 30: Klauber. Pp. 333-336. (San Diego, Calif. : San Diego Society of
Natural History.)
[2412

Bulletins of the Zoological Society of San Diego. No. 17 : Four Papers on the Applications of Statistical Methods to Herpetological Problems. 1: The Frequency Distributions of certain Herpetological Variables; 2: Thlustrations of the Relationship between Populations and Samples; 3: The Correlation between Scalation and Life Zones in San Diego County Snakes; 4 : The Rattlesnakes Listed by Linnaeus in 1758. By L. M. Klauber. Pp. 96. (San Diego, Calif.: Zoological
Society of San Diego.)

Vegetable Cultivation in Hong Kong. By G. A. C. Herklots. Pp iii $+86+v$. (Hong Kong : The Author, The University.) 2 dollars. [11 Field Museum of Natural History. Botanical Series, Vol. 22, No. 7: Additions to our Knowledge of the American and Hawaiian Floras. By Earl Edward Sherff. (Publication 506.) Pp. 405-442. 20 cents. Geological Series, Vol. 8, No. 8: A New Phorothacoid Bird from the Deseado Formation of Patagonia. By Bryan Patterson. (Results of the Marshall Field Paleontological Expeditions to Argentina and Bolivia, 1922-27.) Pp. 49-54. 10 cents. Geological Series, Vol. 8, No. 9 Heteromyids from the Miocene and Lower Oligocene. By Paul 0 . McGrew. Pp. 55-58. 10 cents. Geology Memoirs, Vol. 2: The Upper Ordovician Fauna of Frobisher Bay, Baffin Land. By Sharat Kuma Roy. Pp. 212. 3.50 dollars. Zoological Series, Vol. 24, No. 24 Records of Large Fresh-Water Mussels. By Fritz Haas. Pp. 259-270 15 cents. (Chicago: Field Museum of Natural History.) [11

Sugar-Cane Investigation Committee of Trinidad. Field Experiments on Sugar Cane in Trinidad: Annual Report for 1941. By P. F Turner, with a Brief Description of the Sugar-Cane Soils of Trinidad, by C. F. Charter. Pp. 196. (Trinidad : Government Printer.) [11 Southern Rhodesia. Meteorological Report for the Year ended Southern Rhodesia. Meteorological Report for the Year ended
30th June 1940. Pp. 58. (Salisbury: Government Stationery
Office.) Indian Lac Research Institute. Annual Report for the Financial Year 1940-41. Pp. $\mathrm{v}+41$. (Namkum: Indian Lac Research Institute.)

Smithsonian Miscellaneous Collections. Vol. 101, No. 5 : On SolarConstant and Atmospheric Temperature Changes. By Henryk Arctowski. (Publication 3641.) Pp. vi +62. (Washington, D.C. Smithsonian Institution.)

\section{Catalogues}

Rotameters: British Made Precision Flowmeters for all Gases and Liquids. (RM.120/1.) Pp. 6. (Portslade:- Rotameter Manufacturing Co., Ltd.) 